\title{
Consensus
}

Volume 28

Issue 1 Waterloo Lutheran Seminary Lutheran Life

Article 15

Lectures 1998-2001

$5-1-2002$

\section{The Manichaean body: in discipline and ritual}

Timothy Pettipiece

Follow this and additional works at: http://scholars.wlu.ca/consensus

Part of the Practical Theology Commons

\section{Recommended Citation}

Pettipiece, Timothy (2002) "The Manichaean body: in discipline and ritual," Consensus: Vol. 28 : Iss. 1 , Article 15.

Available at: http://scholars.wlu.ca/consensus/vol28/iss1/15

This Book Reviews is brought to you for free and open access by Scholars Commons @ Laurier. It has been accepted for inclusion in Consensus by an authorized editor of Scholars Commons@ Laurier. For more information, please contact scholarscommons@wlu.ca. 
In each section of the actual commentary, Marshall offers a supplementary bibliography and summarizes how the section fits into the overall flow of the text. A short list of textual variants precedes his detailed exegetical work of the Greek text. Marshall's word studies and syntax analyses are especially useful. He also incorporates and evaluates a substantial variety of viewpoints from other scholars' work. Marshall is well aware of and sensitive to controversial hermeneutical topics in the PE. For instance, in his discussion of women's conduct in the church (1 Timothy 2:8-15), he effectively summarizes various positions, indicating that exegesis is always affected by a priori viewpoints (including his own). Marshall's interpretation emphasizes the circumstantial nature of the exhortation to particular women who were linked with the heterodox teaching addressed throughout 1 Timothy.

Whether or not a person agrees with Marshall's hypothesis of the origins of the PE, this book is an extremely useful tool in terms of clearly articulating the difficulties that critical scholarship has raised, reviewing a wide range of twentieth-century interpretations of the text, and clearly elucidating the Greek text with careful but generally accessible exegetical work. Marshall's approach is balanced, positive and useful, particularly for those who desire a solid exegetical foundation to utilize the PE for application to the modern context.

\section{Mona Tokarek LaFosse}

University of Toronto

\section{The Manichaean Body: In Discipline and Ritual}

Jason David BeDuhn

Baltimore \& London: John Hopkins University Press, 2000 354 pages, \$66.50 Hardcover

The Manichaean movement began in the middle of the third century $\mathrm{CE}$ with the teachings of the Persian prophet Mani, who intentionally set out to establish a universal church for all of humanity, for which he composed his own sacred texts. At the foundation of Mani's theological vision was the belief that the cosmos was the tragic product of a conflict between the powers of Light and the powers of Darkness, and that the ultimate purpose of the pious individual was to assist in the liberation 
of the Light principle from its cosmic prison. This theological vision attracted many followers and eventually spread from North Africa to China. Among its more famous adherents was Augustine of Hippo, who spent part of his life as a Manichaean culditor, or "hearer."

The twentieth century has brought about a veritable Manichaean renaissance. Archaeological expeditions have uncovered (and continue to uncover) substantial amounts of Manichaean texts from Central Asia and Egypt written in a wide variety of ancient languages such as Coptic, Greek, Middle-Persian, Sogdian, Old Turkish, and Chinese. As a result, Manichaeism has received a great deal of attention in the scholarly community and many of the stereotypes bequeathed by the early Christian heresiologists are beginning to be re-examined.

In this fascinating study, Jason BeDuhn challenges the prevailing gnostic interpretation of Manichaeism by bringing to light more details of Manichaean ritual and the practical ways in which Manichaeans attempted to attain salvation. It is an attempt to understand Manichaeism "on its own terms" (234). According to BeDuhn, the Manichaean movement was based not merely on its theological discourse, but on specific "disciplinary regimens" that characterized the Manichaean way of life and distinguished Manichaeans from their social environment. After looking at a wide variety of Manichaean sources from all of the principal regions in which the movement flourished, BeDuhn argues that at the centre of Manichaean ritual practice was the human body, which was viewed as a microcosm in which the macrocosmic struggle between Light and Darkness occurred (117). This struggle was ritually played out through the daily consumption of a sacred meal by the Manichaean elect, who ingested vegetarian foods provided by the auditors in order to facilitate the liberation of the "Living Self" from its entanglement in the cosmos (87).

BeDuhn rejects the scholarly preoccupation with harmonizing the various accounts of Manichaean theology and suggests that any attempt to reconcile their cultural, linguistic, and temporal variations compromises the individual integrity of each account and oversimplifies the movement as a whole. Rather, BeDuhn sees the unifying element of Manichaeism as the ways in which "practice and doctrine are intrinsically interconnected" (121-122). He also acknowledges the methodological problems that result from viewing Manichaean sources simply as literary texts. Instead, BeDuhn makes the important suggestion that, due to the central importance of ritual in Manichaeism, Manichaean texts ought 
to be examined within their ritual and liturgical context.

With this book, BeDuhn makes a very significant contribution to the field of Manichaean Studies by attempting to shift the focus of scholarly attention away from the abstract elements of Manichaean discourse to the concrete rituals and practices that defined the Manichaean identity. In doing so, BeDuhn has helped to clarify a movement that has tended to shock and to perplex so many early Christian and modern commentators.

Timothy Pettipiece

Wilfrid Laurier University

\section{The Making of the Magdalen: Preaching and Popular Devotion in the Later Middle Ages}

Katherine Ludwig Jansen

Princeton, NJ: Princeton University Press, 2001

408 pages, $\$ 30.95$ Softcover

Katherine Ludwig Jansen is Assistant Professor of History at the Catholic University of America, and this book is a revision of her doctoral dissertation. It endeavours to explain why, by the late medieval period, Mary Magdalen had transformed from a shadowy gospel figure to the most popular female saint after the Virgin Mary. Key to this transformation, it argues, is the development of the Magdalen cult both through the lens of medieval preaching, and the responses of those who heard the friars' sermons.

The framework of this analysis begins with the opening of the Fourth Lateran Council in 1215, and concludes with the emergence of the Reformation in 1517 when preachers were confronted by the Protestant challenges to the cult of the saints. Jansen's study is geographically focussed in the Mediterranean regions of Provence and Italy. She claims that this is the setting where devotion to the Magdalen reached its pinnacle in Christendom.

Jansen's argument in this book is cumulative and is divided into four sections. The first section, "The Mendicant Magdalen" (49-142), outlines the development of the figure of Mary Magdalen fashioned by the late medieval mendicant preachers. Jansen suggests that through 